\title{
Financing Structure, R \& D and Sustainable Growth of Small and Medium Enterprises Dan Gao
}

\author{
Jiangsu University of Science and Technology, Zhenjiang, Jiangsu, China
}

Echo_gaodan@163.com

\begin{abstract}
Keywords: Financing structure; Research and development investment; Finance sustainable growth ability; SME Board listed companies
\end{abstract}

\begin{abstract}
This article selects Chinese SME Board listed companies from 2011 to 2015 in five consecutive years of data as the research sample, from the perspective of enterprise sustainable growth, using panel data to study the financing structure, R\&D input and the capacity for sustainable growth. The results of the study found no significant relationship between asset-liability ratio and the sustainable growth ability, significantly positively related to equity financing rate and sustainable growth, endogenous financing and the sustainable growth rate significantly positive correlation; Asset-liability ratio is negatively related to the $\mathrm{R} \& \mathrm{D}$, endogenous financing rate is positively related to the $R \& D$, and rate of equity financing is not associated with $R \& D$.
\end{abstract}

\section{Introduction}

In recent years, Chinese small and medium-sized enterprises play an important role in the development of the economy, technological innovation and other aspects As an important part of the market economy, small and medium-sized enterprises operating difficulties and the collapse of the phenomenon is also common. Accompanied by high growth rates, there are also high mortality and elimination rates. Therefore, the development of small and medium-sized enterprises should not only focus on short-term business performance and corporate stock value, but also focus on the future development trend and the company's sustainable growth.

However, due to Chinese financial market is not mature enough, the enterprise itself also has the problem of the lack of core competitiveness and governance structure is not perfect, which leads to the small and medium-sized enterprises often fall into financing difficulties and unreasonable structure of financing difficulties, seriously hindered the sustainable growth of enterprises.

Compared to the maturation and decline of enterprise, the small and medium-sized plate company another characteristic is that most enterprises located in the growth stage of life cycle and has a stronger vitality, manifests the high-growth, high yield, etc. There are a lot of high-tech enterprises. Technological innovation plays an important role in the growth process. At the same time, R\&D input is high, the cycle is long, income uncertainty etc. So R\&D financing difficulties face higher financing costs because of its risk. In this paper, the empirical study on the financing structure's influence on sustainable growth, and further study for financing structure on its R\&D.

\section{Literature Review}

Financing Structure and Sustainable Growth. The study of the financing structure can be traced back to The MM theory proposed by Modigliani and Miller. The MM theory initially did not consider the corporate income tax and was then revised to argue that the greater the corporate debt, the greater the financial leverage, the greater the value of the company. Robiehek and Myer proposed the trade-off theory, that will produce the financial distress cost and agency cost of debt management, various related costs only in bring the tax benefits and liabilities caused by the debt balance, enterprises can achieve the optimal capital structure. Ross believes that in the case of asymmetric information, the value of the enterprise will increase as the proportion of debt increases. Myers proposed the pecking order theory, that the financing order is endogenous financing, debt financing, equity financing, this is because the endogenous financing of the lowest cost, but also can keep intact 
the interests of existing shareholders, when the endogenous financing cannot meet the needs of enterprise funds, we should consider debt financing firstly, compared to the cost of debt financing, equity financing will be lower, but also will not dilute the enterprise shareholders. Therefore, equity financing is considered at last.

Many scholars have studied the relationship between the financing structure and the growth of enterprises, but they have not reached the same conclusion. Gaver and Gaver's research shows that the asset liability ratio of growth enterprises is significantly lower than that of non growth enterprises. Through empirical research, Harris and Raviv confirm that firm growth is positively related to debt levels. Demirguc and Maksimovic demonstrate the profit of the enterprise and the external financing dependence has a significant negative correlation by the financing plan model, and that external financing is helpful to improve the enterprise's growth rate. Gul, through the empirical study of Listed Companies in Japan and China, concludes that the growth of enterprises and capital structure show a significant negative correlation. Greiner also proved that the growth of enterprises is negatively related to the debt ratio through empirical research. There are a few scholars believe that the financing structure and enterprise growth is not related Titman and Wessels show that, due to the existence of agency problem of debt, debt ratio and corporate growth are negatively correlated with their growth rate as the explanatory variables reflecting the growth in total assets, the results show the relationship between debt ratio and growth is not significant. Chaplinsky and Niehaus research found that the growth of enterprises and financing structure is negatively related.

Chinese scholars have different viewpoints on the relationship between financing structure and growth of enterprises. Shen Genxiang and Zhu Pingfang take the growth rate of net profit and the annual growth rate of sales as the indicators of growth. Empirical studies have found that the debt ratio is negatively related to the growth of enterprises. Zhang Zebin and others found that the growth of enterprises is positively related to the level of debt. Investors believe that the growth of enterprises have good prospects for development, more secure debt. Chen Weiyun and Zhang zongyi take EBIT growth rate, growth rate of total assets as the growth index of corporate debt ratio and growth are related to the conclusion. Xiao Zuoping and Wu Shinong take growth in assets as a measure of the rate of growth of the index, also obtained the growth and debt levels of negative correlation. Zhou Mingyi's research finds that endogenous financing is the most favorable financing way for the growth of SMEs, while there is no evidence that bond financing and equity financing can promote the growth of SMEs. Pan Lisheng and Zhu Jie take the investment opportunity set as the growth substitute variable of the enterprise, and study that the growth of the enterprise and the asset liability ratio have negative correlation. Ouyang Shu uses the $\mathrm{Z}$ model to measure the value of small and medium-sized enterprises exist financing risk, the empirical study found that the risk of debt financing for small firms is positively related to the financing structure and growth, and for the corporate debt financing risk, financing structure and growth of a significant negative correlation.

Financing Structure and R\&D. The researches on the relationship between financing structure and R\&D investment are mostly focused on debt financing and R\&D input. Myers believes that the debt ratio is too high, and will bring great profits to managers' pressure, R\&D higher input will reduce the current profits, affecting the performance of managers, leading to operators without enthusiasm for R\&D input. Ryan and Wiggins think R\&D input is the operator to transfer the assets of the channel from creditors and shareholders. It is difficult to supervise R\&D activities, therefore creditors will not support enterprises engaged in R\&D activities actively. Jensen and Meckling found that the proportion of corporate debt is negatively related to the intensity of R\&D. Baysinger believes that the bank creditors tend to get real assets mortgage, and R\&D investment process will produce a large amount of intangible assets, therefore, creditor will not loan to R\&D project. In addition, the $R \& D$ project is difficult to guarantee a stable cash flow to repay the debt. So firms are either unable or unwilling to support R\&D investments in debt. Williamson's research shows that the asset liability ratio and R\&D intensity is inverted $U$ type. Scherr and Hulburt draw the opposite conclusion, he found that high debt companies are more willing to consider gains from successful development activities and rarely consider the failure of $R \& D$. Therefore, high debt ratio of enterprises put more active investment in research and development. Aivazian have studied the 
impact of debt financing on the company's investment expenditures according the data from Canadian listed companies. The study found that debt financing and investment spending were negatively correlated. He studied the different effects of debt financing on different growth enterprise investment spending, and show a negative correlation between debt financing and investment performance are more significant in low growth enterprises.

Wang Jane's research found that asset liability ratio and R\&D investment is not significantly related. Liu Bin and Cen Lu found that the asset liability ratio is negatively related to the R\&D cost. Because the asset liability ratio of the enterprise is constrained by the debt contract, and the R\&D input of the enterprise is also limited. Chen Haisheng and Lu Dan's research shows that non-state-owned listed companies have significantly higher $R \& D$ intensity than state-owned holding companies, and high debt levels have a significant negative impact on R\&D intensity.

\section{Research hypothesis}

Financing Structure and the Sustainable growth. Agency cost theory holds that the introduction of the debt can reduce agency cost, and constraint the behavior of managers. For listed companies, the introduction of the debt can't reduce the equity agency cost well, debt constraint function can't play very well, and can't give the pressure effectively to maximize the benefits for the company. Small and medium-sized enterprise governance structure is not perfect, the shareholder violate the interests of creditors phenomenon is very serious, the introduction of liabilities is greatly increased debt agency cost. In addition, the relatively small size of the enterprises, management system is not sound, are less able to resist the risk, and vulnerable to the impact of external factors. The introduction of debt increases the financially troubled possibility, makes the bankruptcy risk. The higher asset-liability ratio may not conducive to the growth of the company. Therefore, put forward the hypothesis 1 :

$\mathrm{H}_{1}$ : Asset-liability ratio is negatively related to the company's sustainable growth.

Although equity financing has the advantages of good effect in raising funds and dispersive risk, but the cost of equity financing is higher than internal financing and debt financing, dividend pay from the enterprise's after-tax profits and do not have the tax effect. The growth of small and medium-sized enterprises need a lot of financial support, and dividends reduces the retained earnings of the enterprise. Small and medium-sized enterprises cannot be retained earnings to its own growth. The higher rate of equity financing may have a negative impact on small and medium-sized enterprises growth. Therefore, put forward the hypothesis 2:

$\mathrm{H} 2$ : Equity financing rate is negatively related to the the company's sustainable growth.

Endogenous financing is financing needed money through the enterprise internal. Endogenous financing need lowest cost, but also can avoid equity dilution and the transfer of control, which is helpful for enterprises to make suitable management decisions. Because of internal financing is the enterprise to use their own funds, tend to be very careful, as a result, the endogenous financing risk is low. In addition, the endogenous financing to give the good news to the market, able to display their own financing ability strong, improve enterprise reputation for future financing. Endogenous financing is usually the first choice o corporate finance, its produce positive effects on the growth of the enterprise. Therefore, hypothesized 3:

H3: Endogenous financing rate is positive related to the company's sustainable growth

The Financing Structure and R\&D. R\&D activities is uncertainty, irreversibility and investment cycle is long. While the R\&D input can provide opportunities for growth in the future for the enterprise, but the investment can not achieve in the short term. Therefore, R\&D input face with great risk. In enterprise debt financing, the creditor can only obtain loan interest and have no right to enjoy R\&D risk earnings, therefore, creditors will get higher debt interest rates, which has greatly increased the cost of financing. For the enterprise, the higher the debt ratio, debt service pressure is bigger, the greater the financial risk. If the enterprise $R \& D$ input is more difficult to guarantee funds backflow, it will increase the bankruptcy risk of the enterprise, and pose a threat to the survival of enterprises. For risk aversion, so enterprise is not willing to debt financing to support R\&D input. Therefore, this paper puts forward hypothesis 4 . 
H4: asset-liability ratio is negatively related to the $R \& D$ input.

\section{Results}

This article selects SME Board of Shenzhen Stock Exchange listed companies, the time interval of 2011-2015, and in order to ensure the consistency of data, excluding listed companies since 2011. To avoid extreme value, has been marked as ST and * ST, or within the range of research was marked as ST and * ST companies. And eliminate parts doesn't fit on R\&D input of the company, such as part of the first industry and the tertiary industry of some industries (such as agriculture, forestry and fishing, the service industry, real estate and financial, etc. At the same time, eliminate the interval made significant assets reorganization of the company. After the above screening, get qualified 227 small plate of listed companies.

Model Constructions. The diagnosis research: Financing structure to small and medium-sized enterprise expanding influence; The financing structure to researches and develops the density the influence. Construct the following multi-dimensional return model:

$$
\begin{aligned}
& \mathrm{SGR}=\alpha_{0}+\alpha_{1} \mathrm{~A}_{1}+\alpha_{2} \mathrm{~A}_{2}+\alpha_{3} \mathrm{~A}_{3}+\alpha_{4} \ln \mathrm{ASSET}+\varepsilon \\
& \mathrm{RD}=\beta_{0}+\beta_{1} \mathrm{~A}_{1}+\beta_{2} \mathrm{~A}_{2}+\beta_{3} \mathrm{~A}_{3}+\varepsilon
\end{aligned}
$$

SGR is on behalf of the small and medium-sized enterprise ability of sustainable growth. RD is on behalf of the $R \& D$ investment. $A_{1}$ as the asset-liability ratio, $A_{2}$ for equity financing ratio, $A_{3}$ as the rate of endogenous financing. $A_{1}, A_{2}, A_{3}$ represents the enterprise's financing structure. At the same time, in order to eliminate the influence of enterprise scale, Asset represents the total assets of the enterprise, due to the larger number, take the natural logarithm lnAsset.

In this paper, as of December 31, 2010 in chinese small and medium-sized board listed companies as samples, to remove shall not apply to the R\&D companies, special events, abnormal operating conditions are classified as ST and * ST companies, the data is not complete or discontinuous company, finally it is concluded 298 companies. In order to ensure the data integrity and continuity, observation time is from 2011 to 2015 , a total of five years. In this paper, the data mainly comes from CSMAR, and the manual collection of the annual reports.

The Financing Structure and the Sustainable Growth. In order to determine the model, after F test and Hausman test, the relevant inspection, heteroscedastic inspection. Using Eviews9.0 to regression analysis of model (1), the results as shown in table 1.

Table 1 Financing structure and sustainable growth

\begin{tabular}{c|c|c|c|c}
\hline & & & $\mathrm{T}$ & $\mathrm{P}$ \\
\hline variables & regression coefficient & standard deviation & -5.239 & 0.5991 \\
\hline $\mathrm{c}$ & -0.16068 & 0.03067 & 1.0253 & 0.3051 \\
$\mathrm{~A} 1$ & 0.018521 & 0.01805 & -2.567 & 0.0104 \\
$\mathrm{~A} 1$ & -0.04559 & 0.01779 & 14.325 & 0.0117 \\
A3 & 0.27831 & 0.01942 & 6.9944 & 0.0000 \\
\hline
\end{tabular}

The regression results show that under the confidence level of $95 \%$, the rate of equity financing for sustainable growth is negatively related, to sustainable growth rate of endogenous financing are related. The influence of the asset-liability ratio for sustainable growth is not obvious. The regression results confirm the hypothesis 2 and 3. Asset-liability ratio and capacity for sustainable growth of SMEs has no significant positive correlation.

The Financing Structure and R\&D. Continue with model (1) used in the sample, using panel data analysis of panel data. Through $\mathrm{F}$ test and hausman test, the fixed effects model is determined. Using Eviews9.0 to regression analysis of model (2), the results as shown in table 2. 
Table 2 Financing structure and $R \& D$

\begin{tabular}{c|c|c|c|c}
\hline variables & regression coefficient & standard deviation & $\mathrm{T}$ & $\mathrm{P}$ \\
\hline $\mathrm{c}$ & -0.06634 & 0.01012 & -6.5522 & 0.0239 \\
$\mathrm{~A} 1$ & -0.01590 & 0.00769 & 2.06783 & 0.0389 \\
$\mathrm{~A} 2$ & 0.01195 & 0.00747 & 1.59898 & 0.1101 \\
$\mathrm{~A} 3$ & 0.03637 & 0.00816 & 4.45457 & 0.0034 \\
InAsset & 0.00461 & 0.00031 & 14.6181 & 0.0019 \\
\hline
\end{tabular}

According to the results of the study, asset-liability ratio has no significant impact on the sustainable growth, equity financing rate associated with the sustainable growth.

\section{Conclusions}

Endogenous financing rate is related to the small and medium-sized enterprise sustainable growth. When study the relationship between financing structure and R\&D input, asset-liability ratio is negatively related to the $R \& D$ input., endogenous financing rate is related to $R \& D$ input obviously. According to the study, hypothesis1 4 is confirmed, as well as Pecking Order Theory. The choice of small and medium-sized enterprise financing, the first one is endogenous financing, the second is debt financing, the last is equity financing. Endogenous financing has low cost, little risk and can well-preserved for existing shareholders. So the endogenous financing is the best choice for small and medium-sized enterprise financing. When the internal financing can't meet the demand of enterprise funds, exogenous financing should be considered. Debt financing is lower than the cost of equity financing, and won't dilute shareholders' equity, so give priority to equity financing. When small and medium-sized enterprises are in the actual process of financing, they should consider different sources of financing costs and benefits distribution and try to fund from the multi-channel accesses. High-tech enterprises are the important one of the small and medium-sized enterprises. Their R\&D spending more, the market prospect is good. However, R\&D capital demand is big amount, the risk is high, the cycle is long. So the creditors are not willing to lend money to R\&D projects, even if the creditors agree to the loan, they will be charged a higher interest. For high R\&D density enterprises, the debt financing cost is higher. Therefore, it is advisable that expand financing channels and reduce the proportion of debt financing actively.

\section{References}

[1] Alfred Rappport,1980, Creating Shareholder Value, New York: The Free Press.pp.135 147.

[2] Chan, Louis K., Josef Lakonishok, Theodore Sougiannis.2001, The Stock Market Valuation of Research and Development Expenditures, The Journal of Finance, pp.2431 2455.

[3] James C. Van Home,1988, Sustainable growth modeling, Journal of Corporate Finance, pp.19-25.

[4] Robert C. Higgins,1977, How much growth can a firm afford? Financial Manangement,pp.7 16

[5] Morck, Randall, Andrei Shleifer et al.1988, Manangement Owership and Market Valuation: An empirical analysis, Journal of Financial Economics, Vol.20, pp.293 315.

[6] Jouhaina Gherib,2014, Influence on commitment of companies in sustainable development: empirical evidence from Tunisia, East-West Journal of Economics \& Business, Vol.1,pp. $10 \sim 16$.

[7] Modigliani, F., Miller.M. The Cost of Capital Corporation Finance and the Theory of Investment [J]. The American Economic Review, 1958,48(3) :pp.261 - 297.

[8] Myers,S. C. The Capital Structure Puzzle [J]. The Journal of Finance, 1984, 39(3): pp.575 592.

[9] Demirguc,K. Maksimovic,V.Law,Finance, and Firm Growth[J].The Journal of Finance,1998, 53 ( 6 ) : pp.2107 2137. 
[10] Harris, M.,Raviv,A. Capital Structure and the informational Role of Debt [J] . The Finance, 1990, 45(2): pp. 321 349.

[11] Gul,F.A. Growth Opportunities, Capital Structure and Dividend Policies in Japan[J]. Journal of Corporate Finance,1999,5(2): pp.141 168. 